\title{
DETERMINAN CARBON EMISSION DISCLOSURE PADA PERUSAHAAN BUMN YANG TERDAFTAR DI BURSA EFEK INDONESIA PERIODE 2013-2017
}

\author{
Sari Mujiani ${ }^{1}$, Juardi ${ }^{2}$, Feni Fauziah ${ }^{3}$ \\ ${ }^{1,3}$ Universitas Islam Assyafi-iyah, Bekasi ${ }^{2}$ STIAMI, Jakarta \\ Email: sari.mujiani@gmail.com
}

KETERANGAN ARTIKEL

Riwayat Artikel

Diterima: 1 Mei 2019

Direvisi: 1 Juni 2019

Disetujui: 31 Juni 2019

Klasifikasi JEL

M4, M41

Keywords: Carbon Emission

Disclosure, Profitability,

Leverage and Firm Size

Kata Kunci: Carbon Emission

Disclosure, Profitabilitas,

Leverage dan Ukuran

Perusahaan

\section{ABSTRACT}

Carbon emission disclosure is one of the corporate responsibility forms for environmental preservation that is presented in the financial statements. So that it raises carbon accounting, which is the companies to recognize, measure, record, present and disclose carbon emissions. This study aims to examine and obtain empirical evidence on determinants of carbon emissions disclosure at BUMN companies listed in Indonesia Stock Exchange. Several factors involved in this study, there are profitability, leverage, and firm size. In addition, population of this study is 20 BUMN companies listed in Indonesia Stock Exchange. Meanwhile, sample is selected using purposive sampling technique which produced 75 unit of analysis. This study also uses content analysis techniques on annual reports and/or sustainability reports in 5 years to measure carbon emission disclosure. Data collection is conducted by documentation technique. Moreover, panel data regression with Eviews version 9 applications to select panel estimation technique including chow test, hausman test and langrange multiplier test. Results indicate that profitability have significant and negative effect on carbon emission disclosure. While the leverage and firm size have significant and positive effect on carbon emission disclosure.

\section{ABSTRAK}

Tujuan dari penelitian ini adalah untuk menguji dan mendapatkan bukti empiris pada faktor penentu pengungkapan emisi karbon di perusahaan BUMN yang terdaftar di Bursa Efek Indonesia. Beberapa faktor yang dimbil dalam penelitian ini, ada profitabilitas, leverage dan ukuran perusahaan. Selain itu, populasi penelitian ini adalah 20 perusahaan BUMN yang terdaftar di Bursa Efek Indonesia. Sampel dipilih menggunakan teknik purposive sampling yang menghasilkan 75 data analisis. Penelitian ini juga menggunakan tehnik analisis konten pada laporan tahunan dan/atau laporan keberlanjutan dalam 5 tahun ke depan untuk mengukur pengungkapan emisi karbon. Pengumpulan data dilakukan dengan teknik dokumentasi. Regresi data panel dengan aplikasi Eviews versi 9 untuk melakukan pemilihan teknik estimasi data panel yang meliputi Uji Chow, Uji Hausman, dan Uji Langrange Multiplier. Hasil menunjukkan bahwa profitabilitas berpengaruh signifikan dan negatif terhadap carbon emission disclosure. Adapun leverage dan ukuran perusahaan berpengaruh signifikan dan positif terhadap carbon emission disclosure. 


\section{PENDAHULUAN}

Berubahnya iklim secara global yang saat ini tidak terkendali menyebabkan munculnya berbagai permasalahan. Menurut Griffith et al, 2007 pemanasan global dan risiko perubahan iklim diakui secara internasional sebagai masalah yang signifikan bagi perusahaan. Menurut IPCC (Intergovernmental Panel on Climate Change, 2007), rata-rata suhu permukaan global meningkat dengan laju $0.74^{\circ} \mathrm{C} \pm 0.18^{\circ} \mathrm{C}$ yang mengakibatkan perubahan iklim di berbagai tempat termasuk di Indonesia. Salah satu bukti ilmiah menunjukkan bahwa gas rumah kaca dari aktivitas manusia memperburuk pemanasan global dan perubahan iklim (IPCC, 2007). Aktivitas manusia yang paling besar menyumbang emisi gas rumah kaca adalah aktivitas industri. Perusahaan sebagai pelaku ekonomi yang menjalankan aktivitas industri memiliki peluang besar menghasilkan emisi gas rumah kaca. Perkembangan industri juga menyebabkan banyak hutan yang telah berubah fungsi dari penghasil oksigen dan penyerap gas karbondioksida (paru-paru dunia) berubah menjadi lahan penghasil gas karbondioksida (Kementerian Lingkungan Hidup, 2012). Dampak perubahan iklim yang terjadi di Indonesia meliputi kenaikan suhu permukaan, perubahan cuaca hujan, kenaikan suhu dan tinggi muka laut, peningkatan kejadian iklim dan cuaca ekstrim (RAN-API Bappenas, 2013).

Indonesia telah meratifikasi Protokol Kyoto melalui UU No. 17 Tahun 2004 dalam rangka melaksanakan pembangunan berkelanjutan serta ikut serta dalam upaya menurunkan emisi GRK global. Dalam hal ini terdapat 6 GRK yang ditargetkan penurunannya dalam Protokol Kyoto, yaitu karbon dioksida (CO2), metana (CH4), nitrousoksida (N2O), heksafluorida (SF6), perfluorokarbon (PFC), dan hidrofluorokarbon (HFC). Indonesia sendiri telah berkomitmen mengurangi emisi karbon sebanyak 26 persen pada tahun 2020, yaitu kurang lebih sebanyak 0,67 Gt pada tahun 2020 dan menambahkan 3 persen sampai dengan tahun 2030 (Jannah 2014).

Komitmen Indonesia untuk mengurangi emisi karbon dapat dilihat pula dari adanya Perpres No. 61 Tahun 2011 dan Perpres No. 71 Tahun 2011. Pada pasal 4 Perpres No. 61 Tahun 2011, disebutkan bahwa pelaku usaha juga ikut andil dalam upaya penurunan emisi GRK. Perpres No. 71 Tahun 2011 tentang pencatatan inventarisasi GRK Nasional. Penelitian ini berfokus pada salah satu GRK yaitu $\mathrm{CO} 2$ (emisi karbon) karena perusahaan adalah penyumbang terbesar terhadap perubahan iklim global. Carbon Emission Disclosure di Indonesia masih merupakan voluntary disclosure dan praktiknya masih jarang dilakukan oleh entitas bisnis. Voluntary disclosure adalah pengungkapan butir-butir yang dilakukan secara sukarela oleh perusahaan tanpa diharuskan dan diwajibkan oleh peraturan Bepepam No: KEP347/BL/2012 atau standar akuntansi yang berlaku.

Penelitian ini bertujuan untuk menguji faktor-faktor yang mempengaruhi pengungkapan emisi karbon (carbon emission disclosure) pada perusahaan di Indonesia, yang meliputi profitabilitas, leverage dan ukuran perusahaan. Penelitian ini mengacu pada penelitian yang dilakukan oleh Choi et al (2013). Carbon Emission Disclosure diukur dengan menggunakan beberapa item dalam lima kategori besar yang relevan dengan perubahan iklim dan emisi karbon yang dikembangkan oleh Choi et al (2013) berdasarkan pada lembar permintaan informasi yang diberikan oleh CDP (Carbon Disclosure Project).

Adapun populasi dalam penelitian ini adalah perusahaan BUMN yang terdaftar di Bursa Efek Indonesia periode 2013-2017 karena stakeholder utama pada perusahaan BUMN ini adalah pemerintah. Peneliti tertarik meneliti tentang pengungkapan emisi karbon karena isu ini merupakan konsep baru dan di Indonesia masih sedikit dilakukan penelitian. Berdasarkan uraian latar belakang di atas, 
maka rumusan masalahnya adalah sebagai berikut: (1) apakah Profitabilitas mempengaruhi carbon emission disclosure?, (2) apakah Leverage mempengaruhi carbon emission disclosure?, (3) apakah Ukuran Perusahaan mempengaruhi carbon emission disclosure?. Adapun tujuan dari penelitian ini adalah: (1) untuk menguji dan mengetahui pengaruh Profitabilitas terhadap carbon emission disclosure, (2) untuk menguji dan mengetahui pengaruh Leverage terhadap carbon emission disclosure, serta (3) untuk menguji dan mengetahui pengaruh Ukuran Perusahaan terhadap carbon emission disclosure.

\section{KAJIAN LITERATUR DAN PENGEMBANGAN HIPOTESIS}

\section{Teori Legitimasi}

Teori legitimasi berfokus pada hubungan antara perusahaan dan masyarakat melalui peraturan yang dibuat oleh pemerintah. Sebagaimana yang telah ditekankan oleh Gray et al (1996) bahwa pengungkapan berperan dalam menjembatani perusahaan dengan kelompok masyarakat. Legitimasi adalah persepsi umum atau anggapan bahwa tindakan suatu entitas yang diinginkan, tepat, kepercayaan dan definisi (Burlea dan Popa, 2013). Perusahaan terdorong untuk mendapatkan legitimasi dari masyarakat karena ingin meyakinkan bahwa aktifitas operasi perusahaan telah sesuai dengan norma dan batasan-batasan berdasarkan ketentuan yang berlaku (Deegan dan Unerman, 2006). Legitimasi itu sendiri akan diperoleh perusahaan jika antara masyarakat dan perusahaan terdapat persamaan hasil yang diharapkan, sehingga mengurangi risiko jangka panjang dari tuntutan masyarakat (Deegan et al., 2002). Secara eksplisit dapat dikatakan bahwa teori ini adalah upaya mencari legalitas dari aktivitas yang dilakukan perusahaan, sedangkan secara implisit berarti harapan yang dikehendaki masyarakat, tetapi tidak secara jelas tertulis dalam peraturan legal (Ghozali dan Chariri, 2007).

\section{Teori Stakeholder}

Konsep dari Teori Stakeholder mengatakan bahwa suatu perusahaan tidak bisa lepas dari stakeholder-nya. Stakholeder merupakan kelompok atau individual yang dapat terpengaruh oleh tujuan perusahaan (Rizqi dan Ghozali, 2015). Perusahaan harus memberikan manfaat bagi stakeholder nya (pemegang saham, kreditor, konsumen, supplier, pemerintahan, masyarakat, analis dan pihak lain). Dengan demikian, keberadaan suatu perusahaan sangat mempengaruhi oleh dukungan yang diberikan oleh stakeholder kepada perusahaan tersebut (Putri, 2016). Stakeholder memiliki kemampuan untuk mengendalikan perusahaan dalam menjalankan aktivitasnya termasuk dalam melakukan pengungkapan.

\section{Profitabilitas}

Profitabilitas merupakan rasio yang bertujuan untuk mengetahui kemampuan perusahaan dalam menghasilkan keuntungan dan juga memberikan ukuran tentang tingkat efektifitas manajemen dalam melaksanakan kegiatan operasinya (Kasmir, 2014). Profitabilitas seringkali dijadikan tolak ukur dalam melakukan tanggung jawab lingkungan. Berdasarkan teori legitimasi, masyarakat senantiasa melakukan tekanan kepada perusahaan agar peduli terhadap masalah lingkungan. Perusahaan dengan profitabilitas tinggi lebih mudah dalam menjawab tekanan tersebut karena perusahaan memiliki sumber daya lebih yang dapat digunakan untuk melakukan pengungkapan lingkungan dibandingkan perusahaan dengan profitabilitas rendah sehingga memudahkan perusahaan dalam mendapatkan legitimasi dari masyarakat (Zhang, et al 2013 dalam pratiwi, 2016).

$$
\text { Kontribusi dalam menjaga }
$$
keberlanjutan lingkungan seperti mengganti 
mesin-mesin produksi ramah lingkungan, ikut dalam kegiatan penanaman pohon, berusaha mengurangi emisi dan melakukan pengungkapan akan lebih mungkin dilakukan oleh perusahaan dengan kinerja lebih baik, sebab pengungkapan lingkungan membutuhkan sumber daya lebih besar. Oleh karena itu, tingkat profitabilitas yang tinggi benar-benar sangat membantu perusahaan yang ingin melakukan pengungkapan lingkungan (Irwhantoko dan Basuki, 2016). Hasil penelitian terdahulu dari Majid dan Ghozali (2015), Jannah dan Muid (2014) dan Nizam (2016) menyatakan bahwa profitabilitas berpengaruh positif signifikan terhadap carbon emission disclosure. Berdasarkan teori dan hasil penelitian sebelumnya, dapat disimpulkan bahwa perusahaan dengan profitabilitas yang baik akan dapat memberikan tambahan karyawan atau sumber daya keuangan untuk pengungkapan sukarela. Oleh karena itu, perusahaan dengan kinerja keuangan yang baik diharapkan untuk terlibat dalam carbon emission disclosure, maka hipotesis yang dapat disimpulkan adalah sebagai berikut:

\section{$\mathrm{H}_{1}$ : Profitabilitas berpengaruh positif terhadap carbon emission disclosure}

\section{Leverage}

Pengungkapan lingkungan yang dilakukan oleh perusahaanan dengan kondisi keuangan yang buruk akan menyebabkan kekhawatiran dari debt holders, suppliers, dan customer (Choi, et al 2013). Melakukan pengungkapan sukarela seperti pengungkapan lingkungan akan menambah extra cost bagi perusahaan (Luo, et al 2013) sehingga ada kecendrungan perusahaan dengan leverage yang tinggi akan lebih memilih untuk tidak melakukan pengungkapan demi menghemat biaya selain itu tekanan dari kreditur menjadi alasan perusahaan lebih memilih berkonsentrasi untuk melunasi segala kewajibannya dibandingkan melakukan pengungkapan sukarela.
Teori stakeholder menyatakan bahwa semakin tinggi leverage perusahaan maka tanggung jawab perusahaan terhadap kreditur akan semakin besar sehingga memaksa perusahaan untuk menggunakan sumber dana yang tersedia untuk melunasi utang tersebut daripada untuk melakukan pengungkapan emisi karbon karena melakukan pengungkapan akan menghasilkan biaya yang lebih besar dan dapat menjadi beban bagi perusahaan (Choi, et al 2013). Luo et al (2013) berpendapat bahwa perusahaan dengan leverage yang tinggi hanya memiliki sedikit dana untuk melakukan sistem pelaporan karbon proaktif karena beban utang yang besar. Dengan demikian, tingkat leverage perusahaan akan menggambarkan risiko perusahaan. Penelitian yang dilakukan Luo, et al (2013) dan Suhardi dan Purwanto (2015) menyatakan bahwa leverage berpengaruh negatif signifikan terhadap carbon emission disclosure. Berdasarkan uraian dan penjelasan di atas, maka hipotesis yang dapat disimpulkan adalah sebagai berikut:

$\mathrm{H}_{2}$ : Leverage berpengaruh negatif terhadap carbon emission disclosure

\section{Ukuran Perusahaan}

Perusahaan adalah suatu skala dimana dapat diklasifikasikan besar kecil perusahaan menurut berbagai cara, antara lain total asset, log size, nilai pasar saham dan lain-lain. Menurut Suwito dan Herawati (2005), ukuran perusahaan terbagi menjadi tiga kategori, yaitu perusahaan besar, perusahaan menengah, dan perusahaan kecil. Penentuan ukuran perusahaan ini didasarkan kepada total aset perusahaan. Sumber daya yang dimiliki perusahaan dapat tercermin dari ukurannya. Semakin besar ukuran perusahaan semakin besar sumber daya yang dimiliki (Irwhantoko, 2016). Ukuran perusahaan juga dapat menggambarkan jumlah aktifitas operasional. Perusahaan yang berukuran lebih besar tentu memiliki lebih banyak aktifitas. Segala aktifitas operasional perusahaan tidak jarang berhubungan langsung dengan lingkungan 
sehingga disamping perusahaan menjalankan operasionalnya perusahaan juga perlu menjaga kelestarian lingkungan demi mendukung kinerjanya. Hasil penelitian menunjukkan bahwa ukuran perusahaan mempunyai hubungan yang positif dengan pengungkapan emisi karbon (Jannah dan Muid, 2014). Perusahaan besar memiliki tekanan yang lebih besar dari masalah lingkungan sehingga cenderung untuk meningkatkan respons terhadap lingkungan. Perusahaan besar lebih didorong untuk memberikan pengungkapan sukarela yang berkualitas untuk mendapatkan legitimasi. Perusahaan yang besar diharapkan dapat memberikan lebih banyak pengungkapan karbon sukarela. Hasil Penelitian Majid dan Gozali (2015), Ghomidan Leung (2013), dan Zulaikha (2016) menyatakan bahwa ukuran perusahaan berpengaruh positif terhadap pengungkapan emisi karbon. Berdasarkan uraian dan penjelasan di atas, maka hipotesis yang dapat disimpulkan adalah sebagai berikut:

\section{$\mathrm{H}_{3}$ : Ukuran Perusahaan berpengaruh positif} terhadap carbon emission disclosure

\section{METODE PENELITIAN}

Populasi dan sampel

Populasi yang menjadi objek penelitian ini adalah perusahaan BUMN yang terdaftar di Bursa Efek Indonesia tahun 2013-2017.
Sampel perusahaan yang digunakan dalam penelitian dipilih secara purposive sampling dengan tujuan mendapatkan sampel sesuai dengan tujuan penelitian. Kriteria-kriteria yang digunakan dalam penelitian ini adalah perusahaan BUMN yang terdaftar di Bursa Efek Indonesia selama tahun 2013-2017, perusahaan BUMN yang menyediakan annual report dan sustainability report selama periode pengamatan 2013-2017, serta perusahaan yang mengeluarkan kebijakan pengungkapan emisi karbon minimal satu kebijakan.

\section{Definisi Operasional dan Pengukuran Carbon Emission Disclosure}

Metode pengukuran yang digunakan adalah content analisis. Seperti yang di jelaskan oleh Choi et al (2013) dalam penelitiannya bahwa ada lima kategori besar yang relevan dengan perubahan iklim dan emisi karbon sebagai berikut: risiko dan peluang perubahan iklim (CC/Climate Change), emisi gas rumah kaca (GHG/Greenhouse Gas), konsumsi energi (EC/Energy Consumption), pengurangan gas rumah kaca dan biaya (RC/Reductionand Cost) serta akuntabilitas emisi karbon (ACE/ Accountability of Carbon Emission). Dalam lima kategori tersebut, ada 18 item yang dapat diidentifikasi. Berikut carbon emission disclosure sheet yang ditunjukkan pada tabel berikut:

Tabel 1. Carbon Emission Disclosure

\begin{tabular}{lll}
\hline \multicolumn{1}{c}{ Kategori } & \multicolumn{1}{c}{ Item } \\
\hline $\begin{array}{l}\text { Perubahan Iklim: Resiko dan } \\
\text { peluang }\end{array}$ & $\begin{array}{l}\text { CC-1: Penilaian/deskripsi terhadap risiko } \\
\text { (peraturan/regulasi baik khusus maupun } \\
\text { umum) yang berkaitan dengan perubahan } \\
\text { iklim dan tindakan yang diambil untuk } \\
\text { mengelola risiko tersebut. }\end{array}$ \\
& $\begin{array}{l}\text { CC-2: Penilaian/deskripsi saat ini (dan masa } \\
\text { depan) dari implikasi keuangan, bisnis dan } \\
\text { peluang dari perubahan iklim. }\end{array}$ \\
\hline Emisi Gas Rumah & Kaca & $\begin{array}{l}\text { GHG-1: Deskripsi metodologi yang digunakan } \\
\text { untuk menghitung emisi gas rumah kaca } \\
\text { (GHG/Greenhaouse Gas) }\end{array}$ \\
& (missal protocol GRK atau ISO). \\
\hline
\end{tabular}


Sari Mujiani: Determinan Carbon Emission Disclosure ...

\begin{tabular}{|c|c|}
\hline Kategori & Item \\
\hline & $\begin{array}{l}\text { GHG-2: Keberadaan verifikasi eksternal } \\
\text { kuantitas emisi GRK oleh siapa dan atas dasar } \\
\text { apa. }\end{array}$ \\
\hline & $\begin{array}{l}\text { GHG-3: Total emisi gas rumah kaca (metric ton } \\
\text { CO2-e) yang dihasilkan. }\end{array}$ \\
\hline & $\begin{array}{l}\text { GHG-4: Pengungkapan lingkup } 1 \text { dan 2, atau } 3 \\
\text { emisi GRK langsung. }\end{array}$ \\
\hline & $\begin{array}{l}\text { GHG-5: Pengungkapan emisi GRK berdasarkan } \\
\text { asal atau sumbernya (misal: batu bara, listrik, } \\
\text { dII) }\end{array}$ \\
\hline & $\begin{array}{l}\text { GHG-6: Pengungkapan emisi GRK berdasarkan } \\
\text { fasilitas atau level segmen. }\end{array}$ \\
\hline & $\begin{array}{l}\text { GHG-7: Perbandingan emisi GRK dengan } \\
\text { tahun-tahun sebelumnya. }\end{array}$ \\
\hline \multirow[t]{3}{*}{$\begin{array}{l}\text { Konsumsi Energi (EC/Energy } \\
\text { Consumption) }\end{array}$} & $\begin{array}{l}\text { EC-1: Jumlah energy yang dikonsumsi } \\
\text { (misalnya tera-joule atau PETA-joule) }\end{array}$ \\
\hline & $\begin{array}{l}\text { EC-2: Kuantifikasi energy yang digunakan dari } \\
\text { sumber daya yang dapat diperbaharui. }\end{array}$ \\
\hline & $\begin{array}{l}\text { EC-3: Pengurangan menurut jenis, fasilitas, } \\
\text { atau sigmen. }\end{array}$ \\
\hline \multirow{4}{*}{$\begin{array}{l}\text { Pengurangan Gas Rumah Kaca } \\
\text { dan Biaya (RC/Reduction and } \\
\text { Cost) }\end{array}$} & $\begin{array}{l}\text { RC-1: Detail/rincian dari rencana atau setrategi } \\
\text { untuk mengurangi emisi GRK. }\end{array}$ \\
\hline & $\begin{array}{l}\text { RC-2: Spesifikasi dari target tingkat/level dan } \\
\text { tahun pengurangan emisi GRK. }\end{array}$ \\
\hline & $\begin{array}{l}\text { RC-3: Pengurangan emisi dan biaya atau } \\
\text { tabungan (costs or savigs) yang dicapai saat ini } \\
\text { berbagai akibat dari rencana pengurangan } \\
\text { emisi gas. }\end{array}$ \\
\hline & $\begin{array}{l}\text { RC-4: Biaya emisi masa depan yang } \\
\text { diperhitungkan dalam perencanaan belanja } \\
\text { modal (capital expenditure planning). }\end{array}$ \\
\hline \multirow[t]{2}{*}{$\begin{array}{l}\text { Akuntabilitas Emisi Karbon } \\
\text { (AEC/Accountability of Emission } \\
\text { Carbon) }\end{array}$} & $\begin{array}{l}\text { AEC-1: Indikasi dimana dewan komite (atau } \\
\text { badan eksekutif lainnya) memiliki tanggung } \\
\text { jawab atas tindakan yang berkaitan dengan } \\
\text { perubahan iklim. }\end{array}$ \\
\hline & $\begin{array}{l}\text { AEC-2: Deskripsi mekanisme dimana dewan } \\
\text { (atau badan eksekutif lainnya) meninjau } \\
\text { kemajuan perusahaan mengenai perubahan } \\
\text { iklim. }\end{array}$ \\
\hline
\end{tabular}

Sumber: Jannah dan Muid (2014), dan Wedi et al (2015)

Metode ini dilakukan dengan cara membaca laporan tahunan dan sustainablity report perusahaan-perusahaan sampel untuk menemukan sejauh mana perusahaan melakukan pengungkapan emisi karbon. Luas item pengungkapan emisi karbon menggunakan indeks yang dikembangkan oleh Choi, et al (2013) yang terkonstruksi dari request sheet yang dikembangkan oleh CDP (carbon dislcosure project). Jika perusahaan 
melakukan pengungkapan item sesuai dengan yang ditentukan maka akan diberi skor 1, sedangkan jika item yang ditentukan tidak diungkapkan maka akan diberi skor 0 . Kemudian skor 1 dijumlahkan secara keseluruhan dan dibagi dengan jumlah maksimal item yang dapat diungkapkan lalu dikali $100 \%$.

\section{Profitabilitas}

Rasio profitabilitas juga memberikan ukuran tingkat efektivitas manajemen suatu perusahaan. Hal ini ditunjukkan oleh laba yang dihasilkan dari penjualan dan pendapatan investasi. Profitabilitas diukur dengan menggunakan metode $R O A$, yaitu dengan rumus sebagai berikut:

$$
R O A=\frac{\text { Laba setelah pajak }}{\text { Total Aset }}
$$

\section{Leverage}

Leverage dalam penelitian ini diukur dari rasio total utang dibagi dengan total aset. Rasio tersebut digunakan untuk mengukur seberapa besar aset perusahaan yang dibiayai dengan total utang.

$$
D A R=\frac{\text { Total Utang }}{\text { Total Aset }}
$$

(2)

\section{Ukuran Perusahaan}

Ukuran perusahaan adalah suatu skala dimana dapat diklasifikasikan besar kecilnya sebuah perusahaan diukur dengan mengetahui total aset yang dimiliki perusahaan. Variabel ukuran perusahaan disajikan dalam bentuk logaritma natural.

\section{Ukuran perusahaan $=\operatorname{Ln}($ Total aset $)$}

\section{Teknik Analisis Data}

Metode analisis data yang digunakan dalam penelitian ini adalah metode analisis regresi data panel yang menggabungkan dua data cross section yang terdiri dari 15 perusahaan dan data time series terdiri dari data tahun 2013-2017. Pengolahan data dalam penelitian ini menggunakan program E-views versi 9.0. untuk menganalisis hubungan antara variabel independen dengan dependen dapat digunakan model penelitian sebagai berikut:

$$
Y=\beta_{0}+\beta_{1} X_{1 i t}+\beta_{2} X_{2 i t}+\beta_{3} X_{3 i t}+\varepsilon_{i t}
$$

Di mana:

$Y_{i t}=$ Emission Carbon Disclosure

$\beta_{0}=$ Intersep, konstanta yang merupakan rata-rata nilai $Y_{i t}$ pada saat $X_{1}, X_{2}, X_{3}$ sama dengan nol

$\mathrm{X}_{1}=$ Profitabilitas

$\beta_{1}=$ Koefisien regresi parsial, mengukur nilai rata-rata $Y_{i t}$ untuk setiap unit perubahan $X_{i}$ dengan menganggap $X_{2}$ dan $X_{3}$ konstan

$\mathrm{X}_{2}=$ Leverage

$\beta_{2}=$ Koefisien regresi parsial, mengukur nilai rata-rata $Y_{\text {it }}$ untuk setiap unit perubahan $X_{i}$ dengan menganggap $X_{1}$ dan $X_{3}$ konstan

$X_{3}=$ Ukuran Perusahaan

$\beta_{3}=$ Koefisien regresi parsial, mengukur nilai rata-rata $Y_{\text {it }}$ untuk setiap unit perubahan $X_{i}$ dengan menganggap $X_{1}$ dan $\mathrm{X}_{2}$ konstan

$\varepsilon_{\text {it }}=$ erorterm

\section{HASIL PENELITIAN DAN PEMBAHASAN Deskripsi Objek Penelitian}

Penelitian ini mengambil objek populasi perusahaan BUMN yang terdaftar di Bursa Efek Indonesia dari tahun 2013 sampai 2017. Sampel penelitian yang digunakan yaitu perusahaan yang melakukan pengungkapan emisi karbon. Pengambilan sampel dilakukan dari tahun 2013 sampai dengan 2017. Adapun metod ${ }^{(3)}$ yang digunakan adalah metode purposive sampling.

Berdasarkan data yang diperoleh dari IDX selama lima tahun berutrut-turut diketahui bahwa terdapat 15 perusahaan yang mengungkapkan emisi karbon di tahun 2013- 
2017. Dengan demikian diperoleh sebanyak 15 $X 5=75$ data pengamatan.
Berdasarkan hasil pengolahan data, diperoleh hasil analisis statistik seperti di bawah ini:

\section{Deskripsi Variabel}

Tabel 2. Hasil Analisis Statistik

\begin{tabular}{cccccc}
\hline Variable & Coefficient & Std. Error & t-Statistic & P-value & Keterangan \\
\hline C & -2.474901 & 0.424353 & -5.832179 & 0.0000 & \\
ROA & -0.313093 & 0.154875 & -2.02159 & 0.0479 & Sig. \\
\hline DAR & 0.381636 & 0.062813 & 6.075793 & 0.0000 & Sig. \\
\hline LN & 0.120842 & 0.017198 & 7.026513 & 0.0000 & Sig. \\
\hline R-squared & 0.971027 & Durbin-Watson stat & 1.738901 & \\
\hline $\begin{array}{c}\text { Adjusted R- } \\
\text { squared }\end{array}$ & 0.962385 & & & \\
\hline F-statistic & 112.3717 & & & \\
\hline Prob(F-statistic) & 0.000000 & & & \\
\hline
\end{tabular}

Berdasarkan pengujian pemilihan model estimasi data panel dipilih model Fixed Effects. Pengujian pertama dengan model Fixed Effects dilakukan untuk persamaan regresi linier data panel estimasi model Carbon Emission Disclosure. Persamaan regresi ini terdiri dari variabel independen Profitabilitas, Leverage, Ukuran Perusahaan dan Carbon Emission Disclosure sebagai variabel dependen. Bentuk persamaannya adalah sebagai berikut:

$$
C E D=\alpha_{0}+\beta_{1} R O A+\beta_{2} D A R+\beta_{3} L N+e_{1}
$$

Ketiga variabel independen yaitu profitabilitas, leverage, dan ukuran perusahaan dimasukkan ke dalam regresi. Hasilnya menunjukkan bahwa profitabilitas, leverage, dan ukuran perusahaan secara signifikan berpengaruh terhadap pengungkapan emisi karbon perusahaan. Hal ini dapat dilihat dari tingkat signifikansi untuk variabel-variabel tersebut dibawah 0,05 (5\%). Berdasarkan Nilai Adjusted $R$-square $\left(\mathrm{R}^{2}\right)$ yang dihasilkan sebesar 0,9623 atau $96,23 \%$ menunjukan model dalam penelitian ini sangat kuat. Artinya, carbon emission disclosure dijelaskan oleh profitabilitas, leverage dan ukuran perusahaan sebesar 96,23\% mempunyai arah pengaruh dari seluruh variabel sangat kuat dan sisanya sebesar $4,77 \%$ dijelaskan oleh variabel lainnya di luar model penelitian.

\section{Pembahasan Hasil Penelitian}

Adapun hasil pengujian hipotesis secara ringkas, terlihat pada tabel di bawah ini:

Tabel 3. Hasil Pengujian Hipotesis

\begin{tabular}{|c|c|c|c|c|}
\hline & & Hipotesis & $\begin{array}{c}\text { Temuan } \\
\text { Penelitian }\end{array}$ & Keterangan \\
\hline Variabel Dependen & $\begin{array}{l}\text { Carbon Emission } \\
\text { Disclosure }\end{array}$ & & & \\
\hline Variabel Independen & $\begin{array}{l}\text { Profitabilitas } \\
\text { Leverage } \\
\text { Ukuran Perusahaan }\end{array}$ & $\begin{array}{l}\text { Positif } \\
\text { Positif } \\
\text { Positif }\end{array}$ & $\begin{array}{l}\text { Negatif } \\
\text { Positif } \\
\text { Positif }\end{array}$ & $\begin{array}{l}\text { Signifikan } \\
\text { Signifikan } \\
\text { Signifikan }\end{array}$ \\
\hline
\end{tabular}


Pengaruh Profitabilitas terhadap Carbon Emission Disclosure

Hasil pengujian menunjukkan bahwa profitabilitas berpengaruh signifikan dan negatif terhadap carbon emission disclosure. Hasil penelitian ini sesuai dengan penelitian dari Halimah dan Yanto (2018), bahwa tingkat profitabilitas yang lebih tinggi mengarahkan lebih rendahnya pengungkapan emisi karbon oleh perusahaan. Hasil ini tidak mendukung teori legitimasi yang menyatakan bahwa lebih baik kinerja perusahaan mendorong perusahaan untuk mengekspos lebih banyak pengungkapan sukarela, termasuk carbon emission disclosure. Bahwa, ada alasan untuk dampak negatif profitabilitas pada pengungkapan emisi karbon. Pertama, pengungkapan lingkungan di Indonesia bersifat sukarela. Selain itu, Badan Pengawas Pasar Modal dan Lembaga Keuangan (BAPEPAM-LK) tidak menentukan pengungkapan lingkungan sebagai salah satu persyaratan di Bursa Efek Indonesia. Kedua, perusahaan dengan profitabilitas rendah mengambil keuntungan dari pengungkapan lingkungan untuk tujuan legitimasi. Sebaliknya, perusahaan-perusahaan dengan profitabilitas tinggi tidak perlu memperluas pengungkapan lingkungan mereka sebagaimana adanya dapat mengganggu pencapaian keuangan perusahaan.

\section{Pengaruh Leverage terhadap Carbon Emission Disclosure}

Hasil penelitian menunjukkan leverage berpengaruh positif dan signifikan terhadap carbon emission disclosure. Hal ini menjelaskan bahwa semakin tinggi leverage suatu perusahaan, maka semakin besar pengungkapan terkait pengungkapan emisi karbon. Hal ini sejalan dengan teori stakeholder yang menyatakan bahwa pada dasarnya stakeholder dapat mengendalikan atau memiliki kemampuan untuk mempengaruhi sumber-sumber ekonomi yang digunakan seperti pengungkapan emisi karbon, karena stakeholder utama pada perusahaan BUMN ini adalah pemerintah. Semakin rendah leverage maka perusahaan tetap mengungkapkan pengungkapan terkait lingkungan karena perusahaan berkomitmen untuk melaporkan pengungkapan emisi karbon.

\section{Pengaruh Ukuran Perusahaan terhadap Carbon Emission Disclosure}

Hasil penelitian menunjukkan ukuran perusahaan berpengaruh positif terhadap carbon emission disclosure. Perusahaan besar memiliki tekanan yang lebih besar dari masalah lingkungan sehingga cenderung untuk meningkatkan respon terhadap lingkungan. Perusahaan besar lebih didorong untuk memberikan pengungkapan sukarela yang berkualitas untuk mendapatkan legitimasi. Perusahaan yang besar diharapkan dapat memberikan lebih banyak pengungkapan karbon sukarela. Bahwa perusahaan yang lebih besar memungkinkan perusahaan memiliki sumber daya yang cukup untuk membayar biaya produksi informasi (mengumpulkan dan menghasilkan informasi) bagi pengguna laporan tahunan.

\section{PENUTUP}

Penelitian ini bertujuan untuk menguji faktor-faktor yang mempengaruhi pengungkapan emisi karbon (Carbon Emission Disclosure) pada perusahaan BUMN di Indonesia, yang meliputi profitabilitas, leverage, dan ukuran perusahaan. Analisis pengungkapan emisi karbon diperoleh dari laporan perusahaan yang meliputi laporan tahunan (Annual Report) maupun laporan keberlanjutan (Sustainability Report). Berdasarkan analisis yang telah dilakukan dalam penelitian ini, dapat disimpulkan bahwa profitabilitas, Leverage dan ukuran perusahaan berpengaruh terhadap pengungkapan emisi karbon pada perusahaan BUMN di Indonesia. Dalam penelitian ini, Adjusted $R$ Squre yang dihasilkan sebesar 
96,23\% di mana hal tersebut menggambarkan, bahwa model penelitian ini layak dijadikan referensi dalam pengungkapan carbon emission terkait variabel-variabel yang mempengaruhi dalam penyajian laporan keberlanjutan perusahaan. Penelitian ini mempunyai keterbatasan-keterbatasan yang dapat dijadikan bahan pertimbangan bagi peneliti berikutnya. Pertama, perusahaan yang menjadi sampel penelitian hanya berjumlah 15 perusahaan dengan tahun pengamatan pada tahun 2013-2017. Kedua, adanya pengaruh subjektivitas peneliti dalam menilai luas pengungkapan emisi karbon. Hal ini terjadi karena perbedaan sudut pandang dalam menilai pengungkapan tersebut. Dengan adanya keterbatasan tersebut diharapkan penelitian selanjutnya dapat memperbaiki keterbatasan penelitian ini. Pertama, menambahkan variabel yang dapat menjelaskan pengaruhnya terhadap pengungkapan emisi karbon pada perusahaan di Indonesia seperti tingkat emisi karbon, kualitas corporate governance, dan lain sebagainya. Kedua, memperpanjang tahun pengamatan dan memperbesar sampel penelitian. Ketiga, mengembangkan pengukuran untuk pengungkapan emisi karbon yang sesuai dengan kondisi di Indonesia.

\section{REFERENSI}

Bappenas. (2013). Rencana Aksi Nasional Adaptasi Perubahan Iklim (RAN-API), Kementerian Perencanaan Pembangunan Nasional / Badan Perencanaan Pembangunan Nasional (BAPPENAS). Tersedia di http://perpustakaan.bappenas.go.id/. (Diakses pada 10 Oktober 2018).

Borghei-Ghomi, Zahra and Leung, P. (2013). An Empirical Analysis of the Determinants of Greenhouse Gas Voluntary Disclosure in Australia. Sciedu Press, 2(1), E-ISSN 1927-5994, doi https://doi.org/10.5430/afr.v2n1p110.

Burlea, A, S. and Popa, I. (2013). Legitimacy
Theory, in Encyclopedia of Corporate Social Responsibility. Editor Samuel 0. Idowu, et al. Springer-Verlag Berlin Heidelberg, pp. 1579-1584. Available at http://www.springerreference.com/doc s/html/chapterdbid/333348.html.

Cahya, B. T. (2016). Carbon Emission Disclosure: Ditinjau dari Media Exposure, Kinerja Lingkungan dan Karakteristik Perusahaan Go Publik Berbasis Syariah di Indonesia. NIZHAM, 5(2), pp. 158-175.

Choi, B. B., Lee, D. and Psaros, J. (2013). An analysis of Australian Company Carbon Emission Disclosures. Pacific Accounting Review, 25(1), pp. 58-79.

Deegan, C., Rankin, M. and Tobin, J. (2002). An examination of the corporate social and environmental disclosures of BHP from 1983-1997: A test of legititimacy theory. Accouting, Auditing \& Accounting Journal, 15(3), pp. 312-343.

Deegan, C. and Unerman, J. (2006). Financial Accounting Theory. New York, USA:McGraw-Hill Education.

Ghozali, I. and Chariri, A. (2007). Teori Akuntansi. Semarang: Badan Penerbit Universitas Diponegoro.

Gray, R., Owen, D. and Adams. (1996). Accounting \& Accountability: Changes and Challenges in Corporate Social and Evironmental Reporting. New Jersey, USA: Prentice Hall.

Griffiths, A., Haigh, N. and Rassias, J. (2007). A framework for understanding institutional governance system and climate change: the case of Australia. European Management Journal, 25(6), p. 415.

Halimah, Putri, N. and Yanto, H. (2018). Determinant of Carbon Emission Disclosure at Mining Companies Listed in Indonesia Stock Exchange. International Conference on Economics, Business and Economic Education 2018, Volume 2018.

Irwhantoko and Basuki (2016). Carbon 
Emission Disclosure: Studi pada Perusahaan Manufaktur Indonesi'. Jurnal Akuntansi dan Keuangan, 18(2), pp. 92-104.

Jakarta, S. K. R. (2011a). Peraturan Presiden No. 61 Tahun 2011 tentang Rencana Aksi Nasional Penurunan Emisi Gas Rumah Kaca. Republik Indonesia. . (2011b). Peraturan Presiden No. 71 Tahun 2011 tentang Penyelenggaraan Inventarisasi Gas Rumah Kaca Nasional. Republik Indonesia.

Jannah, R. and Muid, D. (2014). Analisis faktorfaktor yang mempengaruhi Carbon Emission Disclosure pada Perusahaan Indonesia. Journal of Accounting, 3(2), p. 1.

Kasmir. (2014). Analisis Laporan Keuangan. Jakarta: PT Rajagrafindo Persada.

Kementrian, L. H. (2004). Undang-Undang Republik Indonesia Nomor 17 Tahun 2004 tentang Pengesahan Kyoto Protocol to the United Nations Framework Convention On Climate Change (Protokol Kyoto atasKonvensi Kerangka Kerja Perserikatan BangsaBangsa tentang Perubahan Iklim). Repubulik Indonesia. . (2012). Pendalaman Struktur Industri Efisiensi dan Efektivitas dalam Implementasi Industri Hijau. Available at: https://www.google.co.id/ diakses 1 Januari 2019.

Lorenzo, J.-M. P. and Luiz RodriguezDominguez. (2009). Factors Influencing the Disclosure of Greenhouse Gas Emissions in Companies World-Wide.
Journal of Management Decisions, 47(7), pp. 1133-1157.

Luo, L., Tang, Q. and Lan, Y. (2013). Comparison of propensity for carbon disclosure between developing and developed countries. Accounting Research Journal, 26(1), pp. 6-34.

Majid, G. (2015). Analisis faktor-faktor yang mempengaruhi pengungkapan Emisi Gas Rumah Kaca pada perusahaan di Indonesia'. Journal of Accounting, 4(4), pp. 1-11.

Metz, B., Meyer, L. and Bosch, P. (2007). Climate change 2007 mitigation of climate change, Climate Change 2007 Mitigation of Climate Change. doi: 10.1017/CBO9780511546013.

Prafitri, A. and Zulaikha. (2016). Analisis Pengungkapan Emisi Gas Rumah Kaca. Jurnal Akuntansi \& Auditing, 13(2), pp. 155-175.

Pratiwi, P. C. (2016). Pengaruh Tipe Industri, Media Exposure, dan Profitabilitas terhadap Carbon Emission Disclosure. Jurnal Akuntansi, Vol. 4 No. 2.

Suhardi. (2015) Analisis Faktor-Faktor yang Mempengaruhi Pengungkapan Emisi Karbon di Indonesia. Dipenogoro Journal of Accounting, Vol. 4 No. 2, ISSN 23373806.

Suwito, E. and Herawati, A. (2005). Analisis Pengaruh Karakteristik Perusahaan terhadap Tindakan Perataan Laba yang Dilakukan oleh Perusahaan yang terdaftar di Bursa Efek Jakarta. Jurnal dan Prosiding SNA - Simposium Nasional Akuntansi, p. 138. 
